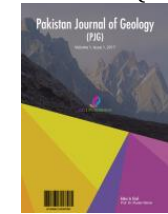

\title{
THE USE OF STRATIGRAPHIC SECTION IN RECORDING QUAGMIRE OF INFORMATION FOR THE FLUVIAL DEPOSITIONAL ENVIRONMENT - A WORKED EXAMPLE IN DISTRICT POONCH, AZAD JAMMU AND KASHMIR, PAKISTAN
}

\author{
Muhammad Yasin ${ }^{1 *}$, Amir shahzad ${ }^{2}$, Noman Abbasi ${ }^{1}$, Umar Ijaz ${ }^{1}$, Zeeshan Khattak ${ }^{3}$ \\ 1 Institute of Geology, University of Azad Jammu and Kashmir, Muzaffarabad, Pakistan. \\ 'Department of Geology, University of Azad Jammu and Kashmir, Neelum campus, Uthmuqam. \\ ${ }^{3}$ Department of Earth and Environmental Sciences, Bahria University Islamabad, Pakistan \\ *Corresponding author email: Rajayasinkhan@gmail.com, Yasin.khan@uajk.edu.pk
}

This is an open access article distributed under the Creative Commons Attribution License, which permits unrestricted use, distribution, and reproduction in any medium, provided the original work is properly cited

\section{ARTICLE DETAILS}

\section{Article History:}

Received 9 July 2017

Accepted 15 October 2017

Available online 2 November 2017

Keywords:

Tape-compass-clinometer, topographic bevels, Sed. Log 3.0 .

\section{ABSTRACT}

The tape-compass-clinometer method was used in gauging the thickness of stratigraphic units on topographic bevels by taping the intercepts. The dips of the beds and slope's inclinations were determined. The appropriate formula was used in the thickness estimation. The graphic columnar section was finally compiled on the Sed. Log 3.0 version to display the geology. The worked example includes the measurement of stratigraphic section of rocks in the District Poonch, Azad Jammu and Kashmir, Pakistan. The study was helpful in understanding the fluvial depositional environment of the Nagri Formation in the region and favours meandering and braided fluvial depositional pattern in continental environment.

\section{INTRODUCTION}

The graphic columnar sections or stratigraphic sections are used to gauge thickness of rocks, to record their sequential descriptions and to position fossils and structures in the rocks [1]. The measurements are useful in understanding the thickness variation, correlating surface data with subsurface well logs, in determining the type locality of formations and understanding repetition of facies $[1,2]$. They are also helpful in the deduction of depositional processes $[2,3]$. The stratigraphic section should be measured in well exposed locations in the small sized area along the drainage, road cuts etc.

The walkover survey is essential before field planning as the time and funds play an important role in the accuracy of survey. However, it is necessary to carry field logistics (such as hammer, handlense, Brunton compass, measuring tape, Hydrochloric acid etc) during the surveys [1,2].

The stratigraphic columns should be prepared according to scale [3]. Both horizontal and vertical scale should be decided. The ascents of slopes, beds thickness and color of rocks determine the lithological characteristics of the stratigraphic units [1].

The descriptions of measured units are recorded in field note book during surveys. An example of measured stratigraphic section is shown in Figure. 1 .

\section{MATERIAL AND METHODS}

\section{a. Tape-Compass-Clinometer Method}

The Tape-Compass-Clinometer method was used in gauging the thickness of stratigraphic units on topographic bevels by taping the intercepts. The dips of beds and the slants of bevels were measured and the thickness was determined by appropriate formula after [4]. On field, the standard tape with the length of $30 \mathrm{~m}$ was used and the offsets were made by compass and tape traverses. However, the keystones of methodologies were worked out in practice after [1]
The Sed. Log 3.0 version was used in final compilation of the graphic columnar sections in order to portray the geology of outcrops [3].

\section{RESULTS AND DISCUSSION}

3.1 Constructing a Graphic columnar section / Stratigraphic Section

The following information is collected from field for the construction of columnar section:

- Location: Afsar Market, District Poonch, Azad Jammu and Kashmir, Pakistan

- $\quad$ Name: Muhammad Yasin

- Date: August, 2014

- Methodology: Measured with Tape compass clinometer method

- Formation: Nagri Formation (Middle Miocene)

- Scale: Both horizental and Vertical

- Nature of base Boundary: Sharp / Graditional

- Lithology: Sandstone, Shale, Claystone

- Texture: Medium to coarse grained

- Sedimentary structures: Pebble imbrications

- Fossils: Leaf imprients

The Graphic columnar section prepared in the field is illustrated in Figure 1.

3.2 WORKED EXAMPLE - The graphic columnar section / Stratigraphic Section of Nagri Formation (Middle Siwaliks) in District Poonch, Azad Jammu and Kashmir, Pakistan

The sandstone of Nagri Formation in the project area (Figure 1) is comprised of medium to coarse grained sandstone, gray to dark gray in colour, salt and pepper textured, interbedded with thick shale beds and claystone [5]. The sandstone also possesses conglomerate invasions and cocreations (Figure 1). The conglomerate includes quartzite and intraformational sandstone, siltstone, shale and clay [6]. Moreover, the 
clasts of carbonate rocks such as limestone, dolomite, the clasts of perlites such as phyllites and the clasts of igneous rocks such as granites are also disseminated in few outcrops $[7,8]$. The conglomerates are sub rounded to round and disc shaped, dominantly matrix supported and the clasts also exhibit poor orientations (imbrications) $[9,10]$. The base of the sandstone is sharp and gradational and shows conformable relationship with interbedded shale and claystone beds (Figure 1) [11]. The intervening shale and claystone beds vary in color from dark to light gray, brown and yellow (Figure 1) with thick beds and have embodied plant remains (leaf fossils) [12].

\section{CONCLUSIONS}

The stratigraphic section was measured in field to estimate thickness and to record all the quagmire of sedimentary information from the rocks. The information plotted on the graphic columnar section (Figure 1) was helpful in understanding the fluvial depositional environment of the Nagri Formation in the area as described below:

- The meandering and braided fluvial system has deposited sandy and pebbly material over shale and claystone.

- The intraformational conglomerates are normally derived from cut banks, deposited and accumulated with reworking.

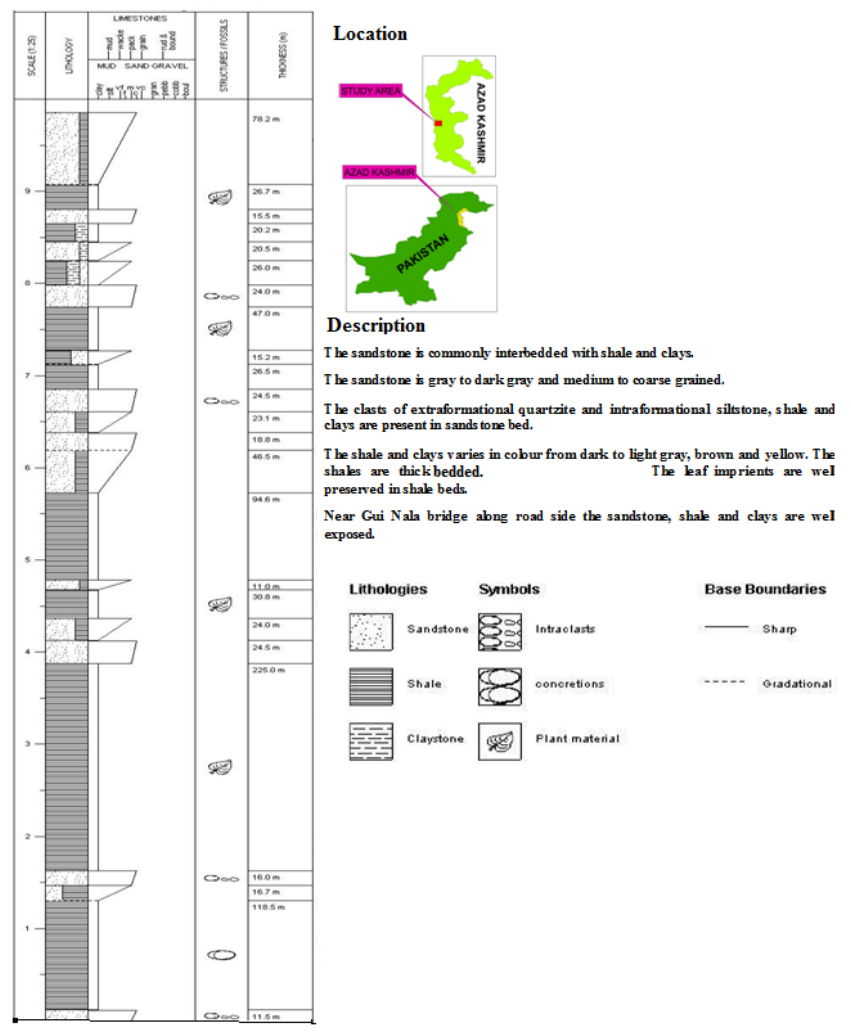

Figure 1: The worked example of graphic columnar section of Nagri Formation (Middle Siwaliks) in District Poonch, Azad Jammu and Kashmir, Pakistan, the area being located towards right hand corner on map.
- The extra formational clasts are accumulated slowly on scour surfaces or on bar tops and even coarse particles form conglomerates in the upper half of channel sand bodies.

- The warm, semiarid and arid climes under hydromorphic conditions are suitable for the origin of calcareous cocreations.

- Moreover, the clasts oriented towards Southwest direction indicate the flow direction towards Southwest and the location of hinterland towards Northeast.

- The plant remains (leaf fossils) in shale beds favors continental origin of the rock.

\section{ACKNOWLEDGEMENTS}

The authors are thankful to the Director Institute of Geology, University of Azad Jammu \& Kashmir, Muzaffarabad for providing financial assistance to carry out the field work in the study area.

\section{REFERENCES}

[1] Compton, R. 1985. Geology in the field. John Wiley and Son., New York. 398 pp.

[2] Coe, A. L., Argles, T. W., Rothery, D.A., and Spicer, R. A. 2010. Geological Field Techniques. John Wiley and Sons, U. K. 323 pp.

[3] Nichols, G. 2009.Sedimentology and Stratigraphy. $2^{\text {nd }}$ edition. John Wiley \& Sons. $419 \mathrm{pp}$.

[4] Palmer, H. S. 1916. Nomo graphic solutions of certain stratigraphic measurements: Economic Geology, 11, 14-29.

[5] Yasin, M. 2014. Petrography and Sedimentology of Neogene sediments in Mang and adjoining areas in the Sub Himalayas, Azad Jammu and Kashmir, Pakistan, Unpublished MS Thesis, University of Azad Jammu and Kashmir, Muzaffarabad, pp. 213.

[6] Hughes D.A., and Lewin J. 1982. A small-scale flood plain. Sedimentology, 29 (6), 891-895.

[7] Reading, H.G., and Collinson, J.D. 1996. Clastic coasts. In: Sedimentary Environments: Processes, Facies and Stratigraphy (Ed. Reading, H.G.). Blackwell Science, Oxford, 154-231.

[8] Laury, R.L. 1971. Stream bank failure and rotational slumping: preservation and significance in the geological record. Bulletin Geological Society of America, 82 (5), 1251-1266.

[9] Gibling, M.R., and Rust, B.R. 1984. Channel margins in a Pennsylvanian braided fluvial deposit: The Morien Group near Sydney, Nova Scotia, Canada. Journal of Sedimentary Petrology, 54 (3), 773-782.

[10] Liu, Y., and Gastaldo, R.A. 1992. Characteristics and provenance of log-transported gravels in a Carboniferous channel deposit. Journal of Sedimentary Research, 62 (6), 1072-1083.

[11] Gile, L.H., Peterson, F.F., and Grossman, R.B. 1965. The K horizon-a master soil horizon of carbonate accumulation. Soil Science, 99 (69), 74-82.

[12] Kraus, M.J. 1999. Paleosols in clastic sedimentary rocks: their geological applications. Earth Science Reviews, 47 (1-2), 41-70.

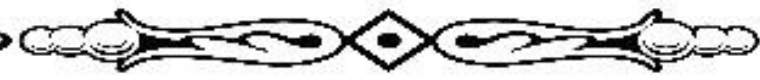

